\title{
PEMBERDAYAAN KADER KESEHATAN MELALUI PELATIHAN SENAM ASMA DAN TEKNIK PERNAPASAN BUTEYKO SEBAGAI UPAYA MENGURANGI KEKAMBUHAN DAN MENURUNKAN GEJALA ASMA PADA PENDERITA ASMA DI PUSKEMAS OLAK KEMANG DAN PUSKESMAS SIMPANG IV SIPIN
}

\author{
Yosi Oktarina, Nurhusna dan Nurlinawati \\ Dosen Fakultas Kedokteran dan Ilmu Kesehatan Universitas Jambi \\ email: oktarinayosi@unja.ac.id; nrhusna81@gmail.com; nurlinawati1983@gmail.com
}

\begin{abstract}
ABSTRAK
Asma termasuk urutan keenam dalam sepuluh penyakit terbesar penyebab kesakitan dan kematian di Indonesia. Serangan asma mengakibatkan seseorang tidak dapat beraktivitas, melakukan kegiatan harian sehingga mengakibatkan produktivitas menurun serta menurunnya kualitas hidup. Asma dapat dikendalikan dengan pengelolaan yang dilakukan secara lengkap, tidak hanya dengan pemberian terapi farmakologis tetapi juga nonfarmakologis. Bentuk terapi non-farmakologis yang telah terbukti dapat menurunkan gejala asma dan mengurangi frekuensi kekambuhan adalah senam asma dan teknik pernapasan buteyko. Kegiatan pengabdian ini bermitra dengan Puskesmas Olak Kemang dan Puskemas Simpang IV Sipin. Kegiatan pengabdian ini bertujuan untuk meningkatkan pengetahuan dan keterampilan kader dalam melakukan senam asma dan teknik pernapasan buteyko. Kader yang merupakan salah satu ujung tombak pelayanan kesehatan dapat mentransferkan ilmu yang telah didapat kepada penderita asma untuk menurunkan gejala asma, frekuensi kekambuhan, dan meningkatkan kualitas hidup penderita asma. Kegiatan pengabdian ini bermitra dengan Puskesmas Simpang IV Sipin dan Puskesmas Olak Kemang. Kegiatan dimulai dengan sosialisasi kegiatan, dilanjukan dengan pemantapan kader, pelatihan senam asma dan teknik pernapasan buteyko. Berdasarkan kegiatan tersebut, dapat disimpulkan setelah dilakukan pelatihan senam asma dan teknik pernapasan buteyko mayoritas peserta telah mengetahuai defenisi, tujuan, manfaat, indikasi, dan kontraindikasi serta prosedur pelaksanaan senam asma dan teknik pernapasan buteyko. Selain itu, mayoritas peserta juga merasa antusias dan tertarik untuk melakukan senam asma dan teknik pernapasan buteyko.
\end{abstract}

\section{Kata Kunci : Asma, Senam Asma, Teknik Buteyko}

\section{PENDAHULUAN}

Pembangunan kesehatan pada hakekatnya merupakan upaya yang dilaksanakan oleh semua komponen bangsa yang bertujuan untuk meningkatkan kesadaran, kemauan, dan kemampuan hidup sehat bagi setiap orang agar terwujud derajat kesehatan masyarakat yang setinggi-tingginya. Meningkatkan derajat kesehatan melalui upaya pemberdayaan masyarakat dalam meningkatnya pengendalian penyakit menular maupun tidak menular. Selama dua dekade terakhir ini, telah terjadi transisi epidemiologis yang signifikan, penyakit tidak menular telah menjadi beban utama. Asma merupakan penyakit yang tidak menular dan termasuk 10 besar penyebab kematian (Kemenkes RI, 2015).

Asma termasuk urutan keenam dalam sepuluh penyakit terbesar penyebab kesakitan dan kematian di Indonesia (WHO, 2014). Berdasarkan hasil Riskesdas nasional tahun 2013 
prevalensi asma nasional di Indonesia mencapai 4,5\% Artinya, dari 220 juta penduduk Indonesia terdapat 9 juta penduduk yang menderita asma (Riskesdas, 2013). Berdasarkan Profil Dinas Kesehatan Kota Jambi ditemukan kasus asma pada tahun 2013 sebanyak 5.930 kasus, tahun 2014 sebanyak 6.603 kasus dan di tahun 2015 kejadian asma di kota Jambi yakni sebanyak 7.624 kasus (Dinkes Kota Jambi, 2015).

Pada umumnya penderita asma akan mengeluhkan gejala batuk, sesak napas, rasa tertekan di dada dan mengi. Pada beberapa keadaan batuk mungkin merupakan satu-satunya gejala. Gejala asma sering terjadi pada malam hari dan saat udara dingin, biasanya bermula mendadak dengan batuk dan rasa tertekan di dada, gangguan tidur disertai dengan sesak napas dan mengi (Soemantri, 2008)

Adapun terapi non farmakologis sebagai upaya untuk mengontrol gejala asma di antaranya adalah senam asma dan teknik pernapasan buteyko. Senam asma diketahui sebagai salah satu teknik pernapasan abdomen yang dapat meningkatkan udara ekspirasi. Di sisi lain, senam asma juga dapat meningkatkan otot-otot pernapasan (Brunner \& Suddarth, 2002). Penelitian yang dilakukan oleh Widjanegara (2014) di Denpasar menunjukkan bahwa senam asma dapat mengurangi kekambuhan dan meningkatkan saturasi oksigen pada penderita asma.

Di samping senam asma, terapi nonfarmakologis untuk asma yang paling mutakhir dan paling ilmiah adalah teknik pernapasan Buteyko yang memang khusus untuk penderita asma. Teknik pernapasan Buteyko ini dapat dilakukan sendiri karena termasuk teknik alami dan sederhana (Rengganis, 2008). Di Australia, sekitar 100 penderita asma dengan hiperventilasi diberikan terapi pernapasan dengan metode Buteyko dan hasilnya menunjukkan adanya penurunan serangan sebesar $91 \%$.

Berdasarkan hasil wawancara dengan Kepala Puskesmas Olak Kemang dan Puskesmas Simpang IV Sipin belum memiliki program rehabilitatif bagi penderita asma. Selain itu kedua puskesmas tersebut juga belum pernah mendapatkan pelatihan senam asma dan teknik pernapasan buteyko tersebut.

\section{METODE PENELITIAN}

Adapun tahapan pelaksanaan kegiatan pengabdian ini adalah :

1. Melakukan kegiatan sosialisasi dengan kepala dan pegawai puskesmas, petugas kesehatan, beserta kader tentang pelatihan teknik pernapasan buteyko

2. Pengidentifikasian kader kesehatan sebagai calon peserta pelatihan teknik pernapasan buteyko

3. Sosialisasi mengenai penyakit asma kepada kader

4. Pelatihan senam asma dan teknik pernapasan buteyko kepada kader

5. Sosialisasi kepada penderita asma mengenai penyakit asma dan simulasi teknik pernapasan buteyko kepada masyarakat oleh kader

Indikator keberhasilan pelaksaan kegiatan ini adalah :

- Indikator input, yaitu :

a. Kader kesehatan bersedia berpartisipasi dalam pelaksanaan kegiatan

b. Ketersediaan sarana dan prasarana dalam pelaksanaan kegiatan 
- Indikator proses, yaitu :

a. Keaktifan bertanya dan berdiskusi saat sosialisasi dan simulasi

b. Pelaksanaan kegiatan sesuai dengan jadwal

- Indikator output, yaitu :

a. Pengetahuan kader tentang penyakit asma, diukur dari kemampuan menjawab pertanyaan dalam kuesioner $>75 \%$ jawaban benar

b. Pengetahuan kader tentang senam asma dan teknik pernapasan buteyko baik, diukur dari kemampuan kader menjawab pertanyaan dalam kuesioner $>75 \%$ jawaban benar

c. Kader mampu melakukan senam asma dan teknik pernapasan buteyko dengan benar

d. Penderita asma bersedia mengikuti kegiatan dari para kader tentang senam asma dan teknik pernapasan buteyko

\section{HASIL DAN PEMBAHASAN}

\section{Pelaksanaan Kegiatan}

Kegiatan pelatihan Senam Asma dan Teknik Pernapasan Buteyko telah dilakukan pada Kamis-Jumat, 12-13 Oktober 2017 di aula Puskesmas Olak Kemang dan Puskesmas Simpang IV Sipin. Kegiatan ini berlangsung dari pukul 08.00-10.00. Adapun jumlah peserta yang hadir dalam kegiatan tersebut berjumlah 30 orang.

Adapun kegiatan tersebut memiliki beberapa tahapan :

1. Sosialisasi kegiatan terhadap petugas puskesmas dan kader

2. Penyuluhan senam asma dan teknik pernapasan buteyko

3. Demonstrasi senam asma dan teknik pernapasan buteyko

4. Evaluasi pengetahuan peserta mengenai senam asma dan teknik pernapasan buteyko

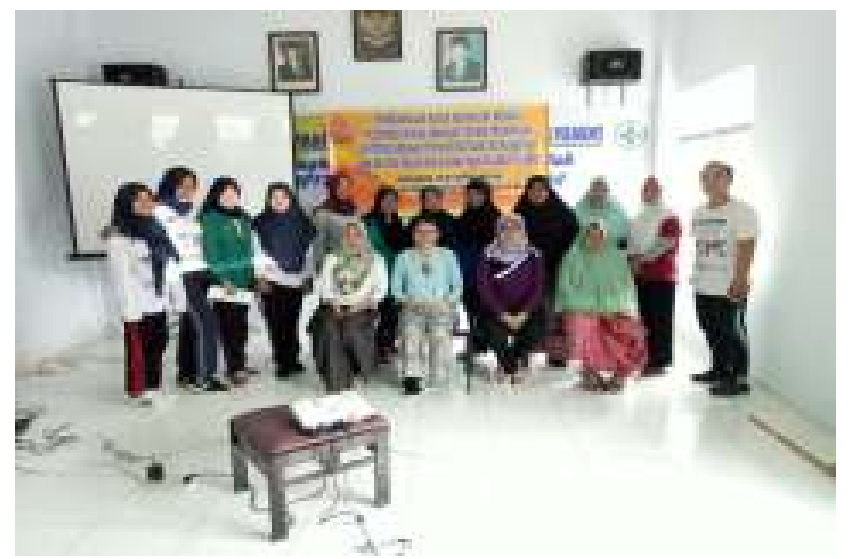

Gambar 1. Foto Bersama Kepala Puskesmas dan

Kader Kesehatan

Kegiatan penyuluhan senam asma dan teknik pernapasan buteyko diawali dengan mengevaluasi gambaran pengetahuan awal peserta mengenai senam asma dan teknik 
pernapsan buteyko. Berdasarkan evaluasi tersebut, didapatkan hasil sebagian besar peserta belum mengetahui mengenai senam asma dan teknik pernapasan buteyko. Selanjutnya, penyampaian materi dilakukan selama 20 menit yang dilanjutkan dengan sesi tanya jawab. Adapun materi penyuluhan yang disampaikan yaitu konsep penyakit asma, defenisi, manfaat, tujuan, indikasi, kontraindikasi, dan prosedur pelaksanaan senam asma dan teknik pernapasan buteyko.

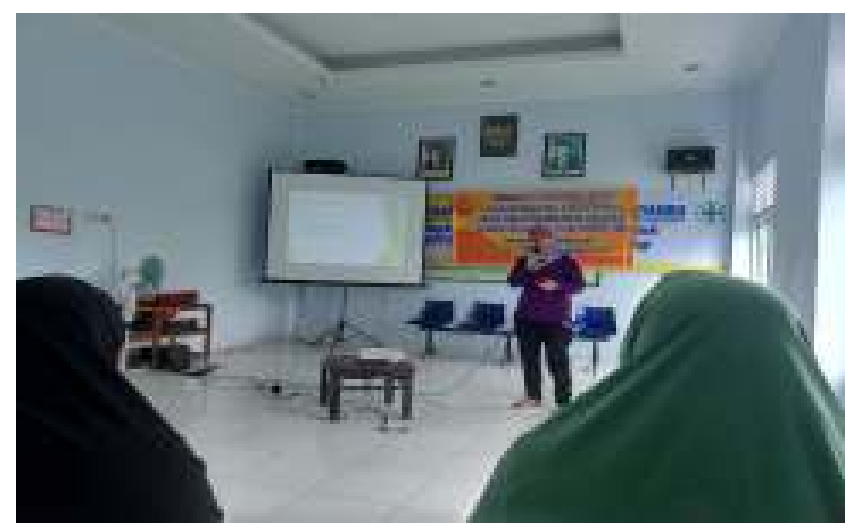

Gambar 2. Penyuluhan Senam Asma dan Teknik

Pernapasan Buteyko

Setelah dilakukan penyuluhan, kemudian dilanjutkan dengan demonstrasi senam asma dan teknik pernapasan buteyko yang dilakukan oleh mahasiswa selaku instruktur. Semua peserta mengikuti demonstrasi yang dipimpin oleh instruktur tersebut. Kegiatan senam asma dan teknik pernapasnag buteyko berlangsung selama 30 menit.

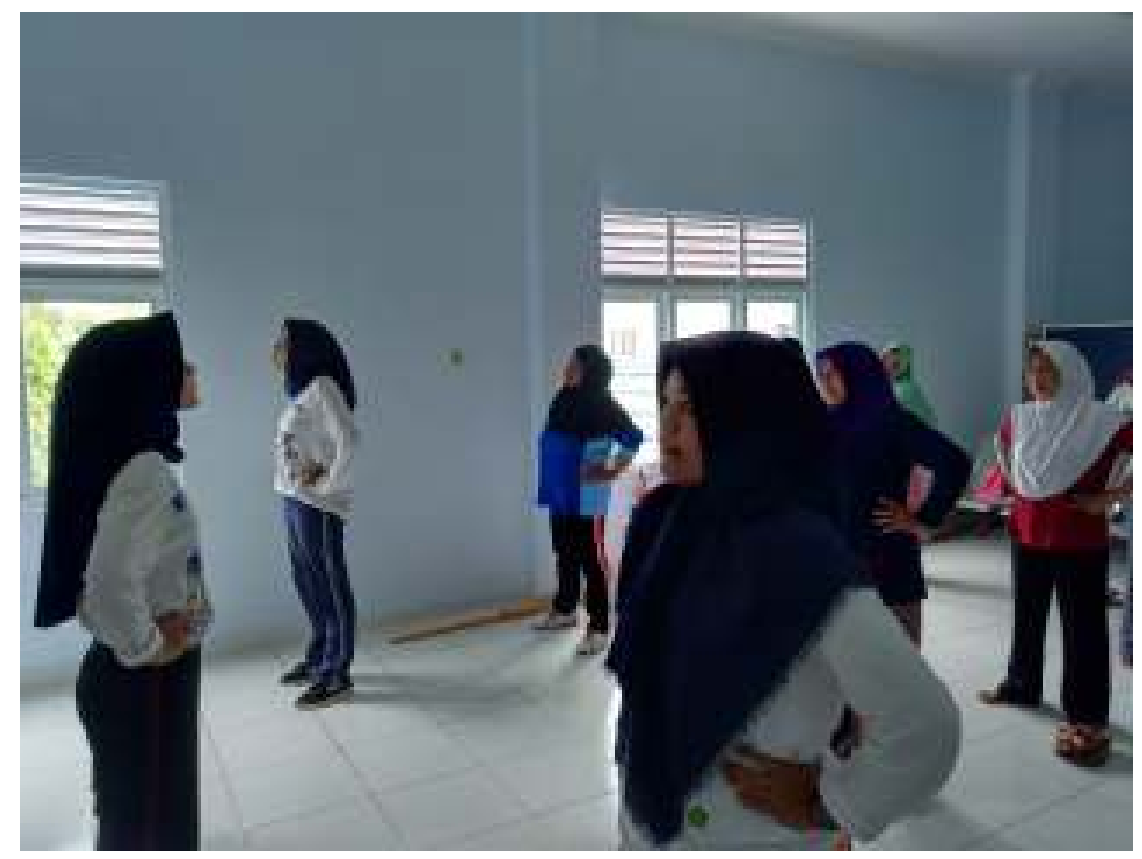

Gambar 3. Demonstrasi Senam Asma dan Teknik Pernapasan Buteyko

Evaluasi aspek kognitif dilakukan setelah dilakukan senam asma dan teknik pernapasan buteyko. Evaluasi dilakukan dengan cara membagikan kuesioner yang terdiri dari sepuluh pertanyaan. Peserta diminta untuk mengisi dan mengumpulkan kembali kuesioner tersebut. 
Tabel 1. Gambaran Karakteristik Responden Berdasarkan Jenisi Kelamin dan Tingkat Pengetahuan

\begin{tabular}{ccc}
\hline Karakterisitik Responden & $\begin{array}{c}\text { Frekuensi } \\
\text { (f) }\end{array}$ & $\begin{array}{c}\text { Persentase } \\
\text { (\%) }\end{array}$ \\
\hline Jenis Kelamin & & \\
- Pria & 10 & 25 \\
- Wanita & 30 & 75 \\
Tingkat Pengetahuan & & \\
- Tinggi & 33 & 82,5 \\
- Rendah & 7 & 17,5 \\
\hline
\end{tabular}

Berdasarkan tabel 3.1 diketahui mayoritas responden berjensi kelamin wanita $75 \%$ dengan tingkat pengetahuan mayoritas tinggi sebesar $82,5 \%$ setelah dilakukan penyuluhan mengenai senam asma dan teknik pernapasan buteyko. Dari hasil kuesioner tersebut dapat dilihat bahwa mayoritas peserta telah memahami pengertian, tanda dan gejala, terapi non farmakologis,tujuan, indikasi, dan kontraindikasi senam asma dan teknik pernapasan buteyko

\section{KESIMPULAN DAN SARAN}

\section{Kesimpulan}

Mayoritas peserta telah memahami pengertian, tanda dan gejala, terapi non farmakologis,tujuan, indikasi, dan kontraindikasi senam asma dan teknik pernapasan buteyko

\section{Saran}

a. Kegiatan senam asma dan teknik pernapasan buteyko hendaknya menjadi program rutin puskesmas

b. Adanya monitoring dan evaluasi yang dilakukan secara berkala terhadap program tersebut

\section{DAFTAR PUSTAKA}

Brunner \& Suddarth. 2002. Buku Ajar Keperawatan Medikal Bedah, Ed. 8, Vol. 1. Jakarta : EGC

Dinas Kesehatan Kota Jambi. 2015. Buku Profil Kesehatan Kota Jambi Tahun 2015. Jambi : Dinas Kesehatan Kota Jambi

Kemenkes RI. (2015). Rencana Strategis Kementrian Kesehatan Tahun 2015-2019. Jakarta: Kementerian Kesehatan.

Rengganis, Iris. (2008). Diagnosis dan Tatalaksana Asma Bronkial. Jakarta : Majalah Kedokteran Indonesia

RISKESDAS. (2013). Laporan Hasil Riset Kesehatan Dasar (RISKESDAS) Nasional. Jakarta : Badan Penelitian dan Pengembangan Kesehatan Departemen Kesehatan RI 
Jurnal Ilmiah Ilmu Terapan Universitas Jambi

Volume 2 Nomor 2 Tahun 2018

Somantri, Iman. (2008). Keperawatan Medikal Bedah: Asuhan Keperawatan pada Pasien dengan Gangguan Sistem Pernapasan. Jakarta: Salemba Medika.

Widjanegara, I.G. (2014). Senam Asma Mengurangi Kekambuhan dan Meningkatkan Saturasi Oksigen Pada Penderita Asma di Poliklinik Paru Rumah Sakit Umum Daerah Wangaya Denpasar. Tesis : Universitas Udayana

WHO. (2014). Asthma. Diunduh melalui

http://www.who.int/mediacentre/factsheets/fs307/en/index.html pada tanggal 17 Februari 2016. 